\title{
USE OF SUGARS TO IMPROVE ROOT GROWTH AND INCREASE TRANSPLANT SUCCESS OF BIRCH (BETULA PENDULA ROTH.)
}

\author{
By Glynn C. Percival' ${ }^{1}$ and Gillian A. Fraser ${ }^{2}$
}

\begin{abstract}
Two field trials undertaken in 1999 and 2003 investigated the influence of a range of sugars applied as a root drench at 25,50 , and $70 \mathrm{~g} / \mathrm{L}(3.4,6.8$, and $10.3 \mathrm{oz} / \mathrm{gal})$ of water on root and shoot growth, chlorophyll fluorescence, photosynthetic rates, and leaf carotenoid and chlorophyll concentrations of birch (Betula pendula Roth.). Irrespective of concentration and year, the sugars galactose and rhamnose had no significant effects on tree growth or leaf photosynthetic properties. Application of the sugar maltose increased shoot and root dry weight in the 1999 trial but had no effect in the 2003 trial. Sucrose, fructose, and glucose increased shoot and root dry weight in both 1999 and 2003 trials; however, growth responses were influenced by the concentration of sugar applied. In many cases, sugar application increased the number of new roots formed by week 6 but had no significant effects on the length of existing roots or shoot growth. By week 24, increases in both root and shoot growth were recorded. Sugar feeding at $25 \mathrm{~g} / \mathrm{L}$ (3.4 oz/gal) of water had no significant effect on leaf chlorophyll fluorescence, photosynthetic rates, or carotenoid and chlorophyll concentrations; however, sugar feeding at 50 and $75 \mathrm{~g} / \mathrm{L}$ (6.8 and $10.3 \mathrm{oz} / \mathrm{gal}$ ) of water reduced these values by week 6 . At the cessation of the experiment, maximal increase in root and shoot growth was associated with a root drench of sucrose at a concentration of $70 \mathrm{~g} / \mathrm{L}$ (10.3 oz/gal) of water in both 1999 and 2003 trials. Lower mortality rates recorded in sugar-treated trees indicate applications of sugars would aid in the survival of young birch trees following transplanting.
\end{abstract}

Key Words. Carbohydrates; resource allocation; gene expression; transplant shock; chlorophyll fluorescence; photosynthesis; chlorophyll; carotenoid; plant vitality.

A major determinant of the performance of a field-grown, transplanted tree is the root:shoot ratio. The transplanting process reduces the root system, which is not paralleled by a reduction in the shoot system. This results in severe water stress because the root system is now of insufficient size to support the tree crown (Haase and Rose 1993). Even when accepted nursery practices are followed, less than $5 \%$ of the actual absorbing root system may be moved with the tree (Watson and Himelick 1982). This extreme state of imbalance between the root system and the crown results in an extended period of stress often described as "transplant shock." Consequently, high mortality rates (30\% to 50\%) are common the first year after planting, with "transplant shock" identified as a major criterion for failure (Johnston and Rushton 1999). In the United Kingdom, where approximately $£ 300$ (US\$450) million is spent annually on tree plantings, even a $5 \%$ loss rate results in high financial loss.

Although a number of factors have been associated with transplant shock, it is now widely believed that survival of newly planted trees is largely dependent on rapid extension of roots that absorb water to replenish transpirational water loss and thus reduce water stress (Gilbertson and Bradshaw 1990; Watson and Himelick 1997). Ideally a cheap, nontoxic, and environmentally friendly compound that can be applied to badly damaged or severely pruned root systems as a dip, soil amendment, and/or foliar spray that increases root vigor (i.e., new root regeneration and elongation of existing roots to rapidly restore the root:shoot ratio) is required.

Until recently, the control of plant growth and development was believed to be coordinated by a range of plant growth regulators, such as auxins that stimulate root growth and cytokinins that stimulate vegetative growth (Percival and Gerritsen 1998). Recent evidence has, however, shown that in plants, sugars such as sucrose, glucose, and fructose function not only as substrates for growth but affect sugarsensing systems that initiate changes in gene expression and subsequent plant growth (Koch 1996). Sugar depletion, for example, upregulates genes for photosynthesis, carbon remobilization, and export, resulting in vegetative or shoot growth. In contrast, incubation of root systems in sugar solutions (i.e., sucrose or glucose) leads to the repression of photosynthetic genes, decreased rates of net photosynthesis, and carbon remobilization in favor of enhanced root development (Koch 1996; Martin et al. 1997). Further, supplementing wheat root systems with sugars (i.e., sucrose, glucose, or fructose) significantly increases lateral root branching and root formation compared with controls (Bingham and Stevenson 1993; Bingham et al. 1997, 1998). This raises the possibility that transplant shock may be reduced by treating transplants during or immediately after with sugars.

Objectives of this investigation were to (1) evaluate the influence a factorial combination of six different sugars (galactose, rhamnose, sucrose, glucose, fructose, and maltose) and three concentrations $(25,50$, and $70 \mathrm{~g} / \mathrm{L}[3.4$, 6.8 , and $10.3 \mathrm{oz} / \mathrm{gal}]$ of water) on root and shoot growth, chlorophyll fluorescence, photosynthesis, and leaf chloro- 
phyll and carotenoid concentrations of birch (Betula pendula) following transplanting.

\section{MATERIALS AND METHODS Plant Material and Experimental Design}

Four-year-old, bare-root birch (Betula pendula Roth.), a transplant-sensitive species (Watson and Himelick 1997), were obtained from a commercial supplier in early January and stored at $6^{\circ} \mathrm{C}\left(42.8^{\circ} \mathrm{F}\right)$ in a refrigerated cold store prior to planting. The physical characteristics of 20 trees selected at random from the 1999 and 2003 trials were destructively analyzed to provide an estimation of stock uniformity for each trial were as follows:

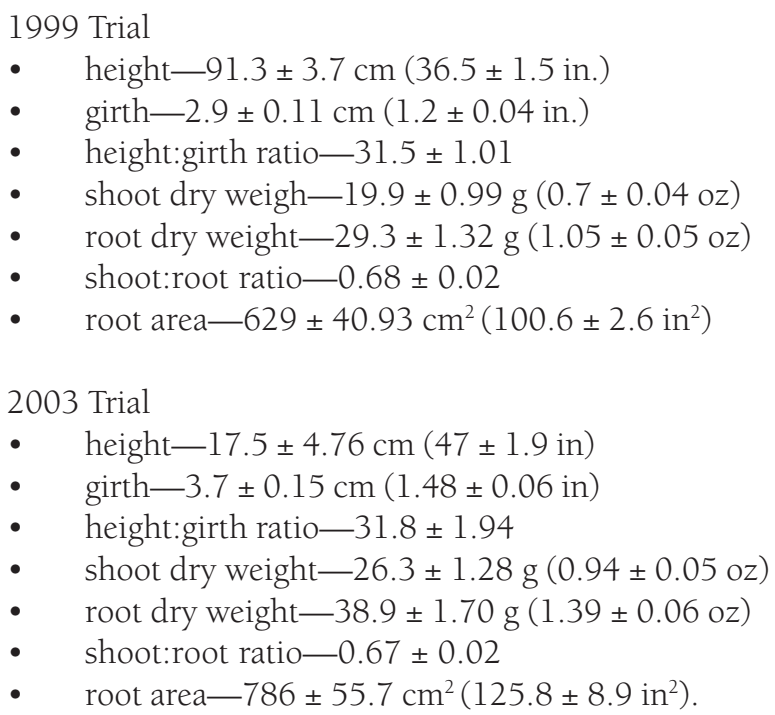

Stem diameter was quantified using Mantax blue precision calipers (Haglöf Sweden AB, Langsele, Sweden) at one-third of the height of the stem and girth calculated using the equation $C=\pi D$, where $C=$ circumference (girth), $\pi=3.14$, and $D=$ diameter. Root areas were quantified using a Delta-T area meter. Leaf, shoot, and root dry weight were recorded after oven drying at $85^{\circ} \mathrm{C}\left(185^{\circ} \mathrm{F}\right)$ for $48 \mathrm{~h}$.

In both 1999 and 2003, the trials were laid out in a randomized complete block design. The block was planned in a square formation to minimize effects of any gradients in soil conditions. Seven treatments (six sugars plus a wateronly control), three concentrations, five individual replications per treatment, and two sampling dates $(6 \times 3 \times 5 \times 2=$ 180 plus 10 controls $=190$ trees per trial) were randomized within the block. The same plot was used for both the 1999 and 2003 trials. Trees were planted by hand at the University of Reading, Shinfield Experimental Station, Reading, UK, at $2 \mathrm{~m}$ (6.6 ft) square spacing on 9 February 1999 and 13 February 2003. Root barriers (RootControl, Green-Tech, Nun Monkton, York) to a depth of $60 \mathrm{~cm}$ (24 in.) were installed around each tree in a square pattern at a distance of $1 \mathrm{~m}(3.3 \mathrm{ft})$ from the tree to eliminate cross contamination of treatments.

The soil was a sandy clay loam containing $4 \%$ to $6 \%$ organic matter with a pH of 6.2. Weeds were controlled chemically using glyphosate (Roundup) prior to planting, and by hand during the trial. Just prior to planting, all trees had $90 \%$ of their root area removed to achieve a root surface area of approximately 60 to $62 \mathrm{~cm}^{2}$ (9.6 to $9.9 \mathrm{in}^{2}$ ) to simulate field harvesting practices.

Two weeks after budbreak (a stage when 80\% to 100\% of foliage has emerged), which, in this investigation occurred on 3 May 1999 and 28 April 2003, a factorial combination of root drenches of six sugars (galactose, rhamnose, sucrose, glucose, fructose, and maltose) at three concentrations $(25,50$, and $70 \mathrm{~g} / \mathrm{L}[3.4,6.8$, and $10.3 \mathrm{oz} /$ gal] of water) were applied.

Each tree received weekly for 4 weeks $1.5 \mathrm{~L}$ (0.4 gal) of sugar solution applied using a watering can. The spout was lightly rested against the main stem at a height of $30 \mathrm{~cm}$ (12 in.), and the sugar solution was allowed to trickle slowly down the main stem. Watering with equal volumes and frequency with water served as the control. Plants received no irrigation or fertilization during the growing season.

\section{Chlorophyll Fluorescence}

Chlorophyll fluorescence was measured at weeks 6 (14 June 1999, 9 June 2003) and 24 (18 October 1999, 13 October 2003) after budbreak. Leaves were adapted to darkness for $30 \mathrm{~min}$ by attaching light-exclusion clips to the leaf surface. Chlorophyll fluorescence was measured using a portable fluorescence spectrometer (Hansatech Instruments Ltd., King's Lynn, UK). Six leaves per tree were selected for measurements (two from the top of the crown, two in the center, and two at the base), and each leaf was tagged to ensure that assessments were taken from the same leaf throughout the entire experiment. Measurements were recorded up to $1 \mathrm{~s}$. The fluorescence responses were induced by a red (peak at $650 \mathrm{~nm}$ ) light of $600 \mathrm{~W} / \mathrm{m}^{2}$ intensity provided by an array of six light-emitting diodes (Shuang and Xu 1999).

Fluorescence values recorded include Fv/Fm as a measure of the photochemical efficiency of photosystem II that is widely used in field studies as an early diagnostic measure of plant stress caused by adverse environmental conditions (Meinander et al. 1996).

\section{Photosynthetic $\mathrm{CO}_{2}$ Fixation}

The light-induced $\mathrm{CO}_{2}$ fixation ( $\mathrm{Pn}$ ) was measured in predarkened (20 min), fully expanded leaves near the top of the canopy (generally about the fourth leaf from the apex) using an infrared gas analyzer (LCA-2 ADC). The irradiance on the leaves was 700 to $800 \mu \mathrm{mol} / \mathrm{m}^{2}$ photosynthetically active radiation saturating with respect to $\mathrm{Pn}$; the velocity of the 
airflow was $1 \mathrm{~mL} / \mathrm{s} / \mathrm{cm}^{2}$ leaf area. Calculation of the photosynthetic rates was carried out according to von Caemmerer and Farquhar (1981). Readings were taken at weeks 6 and 24. Two leaves per tree were selected for measurements. Leaves were tagged to ensure that assessments were taken from the same leaf throughout the experiment.

\section{Leaf Chlorophyll and Carotenoid Analysis}

Chlorophyll and carotenoids were extracted from three leaf samples per tree at weeks 6 and 24 after transplanting by suspending $1 \mathrm{~g}(0.04 \mathrm{oz})$ of fresh tissue in $5 \mathrm{~mL}(0.2 \mathrm{oz})$ of $80 \% \mathrm{v} / \mathrm{v}$ aqueous acetone. After centrifugation in closed vials, an aliquot of the supernatant was transferred to a 1 $\mathrm{cm}$ (0.4 in.) path glass cuvette. Chlorophylls $a$ and $b$ and total carotenoid concentration were calculated according to the equations of Lichtenthaler (1987) following measurement of absorbance at 663, 645, and $480 \mathrm{~nm}$ in a spectrophotometer (PU8800 Pye Unicam, Portsmouth, UK).

\section{Plant Dry Weights and Leaf Area}

At weeks 6 and 24 after budbreak, five trees per treatment were destructively harvested and leaf, shoot, and root dry weight recorded after oven drying at $85^{\circ} \mathrm{C}\left(185^{\circ} \mathrm{F}\right)$ for $48 \mathrm{~h}$. Girth increments were quantified using Mantax blue precision calipers (Haglöf Sweden AB, Langsele, Sweden) from measurements taken $7.5 \mathrm{~cm}$ (3 in.) above the substrate surface. In all cases, root systems were excavated gently by hand and using a spade. Soil was removed by washing with water through a $4 \mathrm{~mm}(0.16 \mathrm{in}$.) screen. Root growth potential (number of new white roots formed $>1 \mathrm{~cm}$ [0.4 in]) and root length (the straight-line distance from the trunk to the furthest root tip) were measured.

\section{Statistical Analysis}

Effects of sugars on growth, chlorophyll fluorescence, photosynthetic rates, chlorophyll and carotenoid concentrations, and significant interactions between sugar and concentration were determined by two- and one-way analyses of variance (ANOVA) following checks for normality and equal variance distributions. Differences between treatment means were separated by the least significance difference (LSD) at the 95\% confidence level $(P>0.05)$ using the Genstat V program.

\section{RESULTS}

There was no significant interaction between sugar type and concentration for any parameter in either the 1999 or 2003 trials (Table $1^{*}$ ). Sugar concentration affected only leaf dry weight in 2003. Sugar type affected chlorophyll and carotenoid content and Fv/Fm ratio in 1999 and root dry weight and Fv/Fm ratio in 2003.

\footnotetext{
*Tables for this article appear on pp. 73-77.
}

No significant effects on growth or leaf photosynthetic properties were recorded following application of galactose, rhamnose, and maltose (2003 trial only), irrespective of concentration applied. For reasons of clarity, nonsignificant data are not shown.

\section{Chlorophyll Fluorescence, Photosynthesis, and Chlorophyll and Carotenoid Concentrations and Mortality}

No significant effects on Fv/Fm, Pn, or leaf chlorophyll and carotenoid concentrations were recorded following application of any of the sugars tested at a concentration of $25 \mathrm{~g} / \mathrm{L}$ (3.4 oz/gal), with one exception: significantly reduced leaf carotenoid concentrations were found in trees supplemented with fructose at week 6 in the 2003 trial. At week 6 in both the 1999 and 2003 trials, leaf chlorophyll and carotenoid concentrations and Pn and Fv/Fm were significantly lower $(P<0.05)$ in trees supplemented with sucrose, glucose, fructose, and maltose (1999 trial) at concentrations of 50 and $70 \mathrm{~g} / \mathrm{L}$ ( 6.8 and $10.3 \mathrm{oz} / \mathrm{gal}$ ) compared with control values (Tables 2 and 3). Exceptions to this include, in the 1999 trial, fructose (leaf chlorophyll, carotenoid concentrations and $\mathrm{Fv} / \mathrm{Fm}$ values) and maltose (Pn) applied at $50 \mathrm{~g} / \mathrm{L}(6.8 \mathrm{oz} / \mathrm{gal})$, where no significant effects were recorded.

In the 2003 trial, no significant effects on Fv/Fm were found following application of $50 \mathrm{~g} / \mathrm{L}(6.8 \mathrm{oz} / \mathrm{gal})$ of sucrose, fructose, and glucose; on Fv/Fm following application of $70 \mathrm{~g} / \mathrm{L}$ (10.3 oz/gal) of glucose; on leaf chlorophyll concentration following application of $50 \mathrm{~g} / \mathrm{L}(6.8 \mathrm{oz} / \mathrm{gal})$ of fructose; or on Pn following application of $70 \mathrm{~g} / \mathrm{L}$ (10.3 oz/ gal) of glucose.

In both 1999 and 2003 trials, no significant effects on Fv/Fm or Pn, or on leaf chlorophyll and carotenoid concentrations were recorded at week 24 . Results indicate a reduction in leaf photosynthetic properties by week 6 following application of sucrose, glucose, and fructose at 50 and $70 \mathrm{~g} / \mathrm{L}$ (6.8 and $10.3 \mathrm{oz} / \mathrm{gal})$. By week 24 , a rising chlorophyll and carotenoid content and subsequent increase in $\mathrm{Fv} / \mathrm{Fm}$ were mirrored by increased leaf photosynthetic rates $(\mathrm{Pn})$. No significant effects on the ratio of chlorophyll $a: b$ (65:35) compared to controls were recorded (data not shown).

\section{Plant Growth}

Applications of sucrose, glucose, and fructose induced similar alterations in growth of birch in both 1999 and 2003 experiments (Tables 4 and 5). Irrespective of sugar type and concentration, no significant effects on root length, girth, or leaf and shoot dry weight were recorded at week 6 . However, a significant increase $(P<0.05)$ in root growth potential and root dry weight was recorded following applications of sucrose, glucose, fructose, and maltose (1999 trial) at all 
three concentrations, with the following exceptions. In the 1999 trial, sucrose and glucose at $25 \mathrm{~g} / \mathrm{L}$ (3.4 oz/gal) (root dry weight); glucose at $50 \mathrm{~g} / \mathrm{L}(6.8 \mathrm{oz} / \mathrm{gal})$ (root growth potential); and maltose at $25 \mathrm{~g} / \mathrm{L}$ (3.4 oz/gal) (root growth potential, root dry weight) and at $70 \mathrm{~g} / \mathrm{L}$ (10.3 oz/gal) (root dry weight), where no significant effects occurred. In the 2003 trial, sucrose and fructose at $25 \mathrm{~g} / \mathrm{L}(3.4 \mathrm{oz} / \mathrm{gal}$ ) (root growth potential); fructose at $70 \mathrm{~g} / \mathrm{L}$ (10.3 oz/gal) (root growth potential); sucrose at $25 \mathrm{~g} / \mathrm{L}(3.4 \mathrm{oz} / \mathrm{gal})$; and glucose at $70 \mathrm{~g} / \mathrm{L}$ (10.3 oz/gal) (root dry weight), where no significant effects were recorded.

By week 24 (1999 trial), a significant increase $(P<0.05)$ in growth was recorded, with the exceptions of glucose and fructose at $25 \mathrm{~g} / \mathrm{L}$ ( $3.4 \mathrm{oz} / \mathrm{gal})$ (root dry weight); glucose at $50 \mathrm{~g} / \mathrm{L}$ ( $6.8 \mathrm{oz} / \mathrm{gal}$ ) (root length); sucrose, fructose, glucose, and maltose at $25 \mathrm{~g} / \mathrm{L}$ ( $3.4 \mathrm{oz} / \mathrm{gal})$ (root growth potential); sucrose, fructose, and glucose at $25 \mathrm{~g} / \mathrm{L}$ (3.4 oz/gal); maltose at 25,50 , and $70 \mathrm{~g} / \mathrm{L}(3.4,6.8$, and $10.3 \mathrm{oz} / \mathrm{gal}$ ) (girth, shoot dry weight); and fructose and glucose at $25 \mathrm{~g} / \mathrm{L}$ (3.4 oz/gal) (leaf dry weight), where values were not significantly higher than controls.

At week 24 in the 2003 trial, a significant increase $(P<$ $0.05)$ in growth was recorded, with the exceptions of sucrose and fructose at 25 and $70 \mathrm{~g} / \mathrm{L}(3.4$ and $10.3 \mathrm{oz} / \mathrm{gal}$ ) (root dry weight); sucrose, fructose, and glucose at $50 \mathrm{~g} / \mathrm{L}$ (6.8 oz/gal), glucose at $25 \mathrm{~g} / \mathrm{L}(3.4 \mathrm{oz} / \mathrm{gal})$, and fructose at $70 \mathrm{~g} / \mathrm{L}(10.3 \mathrm{oz}$ ) (root length); sucrose and fructose at 25 and $70 \mathrm{~g} / \mathrm{L}(3.4$ and $10.3 \mathrm{oz} / \mathrm{gal})$, and glucose at $70 \mathrm{~g} / \mathrm{L}(10.3$ oz/gal) (root growth potential); sucrose and glucose at $25 \mathrm{~g} /$ $\mathrm{L}(3.4 \mathrm{oz} / \mathrm{gal})$, and fructose and glucose at 50 and $70 \mathrm{~g} / \mathrm{L}$ (6.8 and $10.3 \mathrm{oz} / \mathrm{gal}$ ) (girth); sucrose, fructose, and glucose at $25 \mathrm{~g} / \mathrm{L}(3.4 \mathrm{oz} / \mathrm{gal})$, glucose at 50 and $70 \mathrm{~g} / \mathrm{L}$ (6.8 and 10.3 oz/gal) (shoot dry weight); and sucrose, fructose, and glucose at $25 \mathrm{~g} / \mathrm{L}$ (3.4 oz/gal) (leaf dry weight), where values were higher, but not significantly more so than controls.

In both 1999 and 2003 trials, the highest increases in girth and in root, shoot, and leaf dry weight at the cessation of the experiment were recorded following applications of sucrose as a root drench at a concentration of $70 \mathrm{~g} / \mathrm{L}$ (10.3 oz/gal). Application of the sugars tested in this investigation to root systems of birch following severe root pruning reduced mortality from 15\% (controls) to zero in the 1999 trial and 5\% to zero in the 2003 trial.

\section{DISCUSSION}

Results of this investigation show that application of the sugars sucrose, fructose, and glucose as a root drench improved root growth of young, newly transplanted birch following severe root pruning. Likewise, reduced mortality and increased shoot and leaf dry weight and girth in treated trees recorded at the cessation of both the 1999 and 2003 field trials indicate applications of sugars would aid in the survival of young birch trees following transplanting.
Further research is required to determine whether applying sugars to root systems of other tree species would induce similar beneficial responses.

Improved root vigor, as assessed by higher root growth potential values at week 6 , in trees supplemented with sucrose, fructose, and glucose in both trials and maltose in the 1999 trial and reduced photosynthetic rates recorded at the same time indicate that these sugars were used as direct substrates for root growth (Lindqvist and Asp 2002). Sucrose is the major photoassimilate transported from source to sink tissues in birch that is hydrolyzed into glucose and fructose to provide energy via respiration, while maltose is the predominant sugar in barley (Salisbury and Ross; 1985; Lindqvist and Asp 2002). Rapid uptake, transfer, and breakdown mechanisms that naturally exist within plants for utilizing these four sugars may account for the stimulatory root growth responses recorded by week 6 . Sugars such as galactose and rhamnose are not directly used as substrates for growth but have been shown to play important roles in plant defense systems (Percival et al. 1998). This may account for their failure to induce any alterations in growth and leaf photosynthetic properties recorded in this investigation.

No significant effects on growth of birch were recorded following application of the sugar maltose in the 2003 trial. Contrary to this finding, significant increases in growth were recorded in the 1999 trial. Such a response is disadvantageous to professionals involved in urban tree care where products with repeatability and reliability are required.

Although not explored, alterations in gene expression may explain the growth and leaf photosynthetic responses recorded at the whole plant level. Reduced photosynthetic rates, chlorophyll fluorescence, and leaf chlorophyll and carotenoid concentrations, coupled with increased root growth potential and root dry weight recorded at week 6 , would indicate repression of photosynthetic genes and upregulation of genes involved in root vigor in the short term (Koch 1996; Martin et al. 1997). By week 24, the genetic balance is restored as reflected by no significant difference in leaf chlorophyll fluorescence, photosynthetic rates, and leaf chlorophyll and carotenoid content between treated and control trees. Alternately, biologically active organic molecules such as sugars, sea weed extracts, and betaines, when applied to soils, have been shown to induce changes in the naturally occurring soil rhizosphere populations-resulting in alterations to plant nutrient uptake patterns (Pattison 1994; Walsh 1997). Such changes may also have contributed to improved growth and reduced mortality recorded in this investigation (Blunden and Woods 1969; Finnie and van Staden 1985).

Rapid root regeneration is associated with successful transplant establishment. Significant increases in the root growth potential recorded by week 6 indicate short-term 
stimulatory effects of sugars on root regeneration. Consequently, the higher root growth potential values associated with sugar applied to birch may reduce drought-related transplant shock symptoms permitting increased shoot and leaf growth recorded at 24. Work elsewhere has shown that exogenously applied auxins (a plant hormone involved in root metabolism) promote root initiation and increase numbers and length of existing roots of a range of plants by 6- to 18-fold in some instances (Looney and McIntosh 1968; Struve and Moser 1984; Struve 1990); however, a delay exists between each process, with each requiring a different optimum auxin concentration. The concentration for growth tends to be lower than that for initiation (Kelly and Moser 1983). Results of this investigation indicated a sugar concentration of at least $25 \mathrm{~g} / \mathrm{L}$ (3.4 oz/gal) is required before significant effects on root formation occur. By week 24 , significant effects on root length were recorded. Consequently, a sugar concentration of at least $25 \mathrm{~g} / \mathrm{L}(3.4 \mathrm{oz} / \mathrm{gal})$ is initially optimal for root formation such that, with time, dilution by watering or degradation in the soil possibly resulted in a concentration inducing elongation of existing roots.

In conclusion, applications of sugars improved root and shoot growth and reduced transplant losses in birch; however, further studies are required to understand the mechanistic basis by which this occurred and to determine whether sugars can provide useful soil amendments for landscape- sized trees greater than $50 \mathrm{~mm}$ (2 in.) diameter. Likewise, the practicality of applying sugars at weekly intervals for the first month commencing budbreak needs to be addressed. This is an area worthy of further research given the fact that sugars are water soluble, nontoxic, environmentally safe, and inexpensive to purchase.

Acknowledgments. The author is grateful for funding from the TREE Fund (Hyland Johns grant program).



\section{LITERATURE CITED}

Bingham, I.J., and E.A. Stevenson. 1993. Control of root growth: Effects of carbohydrates on the extension, branching and rate of respiration of different fractions of wheat roots. Physiol. Plantarum 88:149-158.

Bingham, I.J., J.M. Blackwood, and E.A. Stevenson. 1997. Site, scale and time course adjustments in lateral root initiation in wheat following changes in $\mathrm{C}$ and $\mathrm{N}$ supply. Ann. Bot. 80:97-106.

1998. Relationship between tissue sugar content, phloem import and lateral root initiation in wheat. Physiol. Plantarum 103:107-113.
Blunden, G., and Woods, D.L. 1969. Effect of carbohydrates in seaweed fertilizers, pp 647-653. In Proceedings of the 6th International Seaweed Symposium.

Finnie, J.F., and van Staden, J. 1985. The effect of seaweed concentrate and applied hormones on in vitro cultured tomato roots. J. Plant. Physiol. 120:215-222.

Gilbertson, P., and A.D. Bradshaw. 1990. The survival of newly planted trees in inner cities. Arboric. J. 14:287-309.

Haase, D.L., and R. Rose. 1993. Soil moisture stress induces transplant shock in stored and unstored 2+0 Douglas-fir seedlings of varying root volumes. For. Sci. 39:275-294.

Johnston, M., and B.S. Rushton. 1999. A Survey of Urban Forestry in Britain. University of Ulster, Coleraine, UK.

Kelly, R J., and B.C. Moser. 1983. Root regeneration of Liriodendron tulipifera in response to auxin, stem pruning, and environmental conditions. J. Am. Soc. Hortic. Sci. 108:1085-1090.

Koch, K. 1996. Carbohydrate modulated gene expression in plants. Annu. Rev. Plant. Physiol. 47:509-540.

Lichtenthaler, H.K. 1987. Chlorophylls and carotenoids: Pigments of photosynthetic biomembranes. Methods Enzymol. 148:350-382.

Lindqvist, H., and H. Asp. 2002. Effects of lifting date and storage time on changes in carbohydrate content and photosynthetic efficiency in three deciduous species. J. Hortic. Sci. Biotechnol. 77(3):346-354.

Looney, N.E., and D.L. McIntosh. 1968. Stimulation of pear rooting by preplant treatment of nursery stock with indole-3-butyric acid. Proc. Am. Soc. Hortic. Soc. 92:150-154.

Martin, T., H. Hellmann, R. Schmidt, L. Willmitzer, and W.B. Frommer. 1997. Identification of mutants in metabolically regulated gene expression. Plant J. 11(1):53-62.

Meinander, O., S. Somersalo, T. Holopainen, and R.J. Strasser. 1996. Scots pine after exposure to elevated ozone and carbon dioxide probed by reflectance spectra and chlorophyll $a$ fluorescence transients. J. Plant Physiol. 148:229-236.

Pattison, D. 1994. Morphological changes induced in Phytophthora cinnamomi Rands by extract of Ascophyllum nodosum and effects on soilborne microbial populations. Ph.D. thesis. The University of Strathclyde in association with Scottish Agricultural College (SAC), UK.

Percival, G.C., M.S. Karim, and G.R. Dixon. 1998. The influence of light enhanced glycoalkaloids on resistance to Fusarium sulphureum and F. solani var. coeruleum in potato. Plant Pathol. 47:665-670.

Percival, G.C., and J. Gerritsen. 1998. The influence of plant growth regulators on root and shoot growth of containerised trees following root removal. J. Hortic. Sci. Biol. 73(3):353-359.

Salisbury, F.B., and C.W. Ross. 1985. Plant Physiology (3rd ed.). Wadsworth, Belmont, CA. 
Shuang, S.H., and D.A. Xu. 1999. Light-induced increase in initial chlorophyll fluorescence Fo level and the reversible inactivation of PS II reaction centers in soybean leaves. Photosynth. Res. 61:269-280.

Struve, D.K. 1990. Root regeneration in transplanted deciduous nursery stock. HortScience 25: 266-270.

Struve, D.K., and B.C. Moser. 1984. Root system and root regeneration characteristics of pin and scarlet oak. HortScience 19:123-125.

von Caemmerer, S., and G.D. Farquhar. 1981. Some relationships between the biochemistry of photosynthesis and the gas exchange of leaves. Planta 153:376-387.

Walsh, U.F. 1997. The Effects of Ascophyllum nodosum Liquid Seaweed Extract on Microbial Growth, Activity and Pathogenicity. Ph.D. thesis. The University of Strathclyde in association with Scottish Agricultural College (SAC), UK.

Watson, G.W., and E.B. Himelick. 1982. Root distribution of nursery trees and its relationship to transplanting success. J. Arboric. 8:225-229.
1997. Principles and Practice of Planting Trees and Shrubs. International Society of Arboriculture, Champaign, IL.

${ }^{1 *}$ R.A. Bartlett Tree Research Laboratory, Europe

The University of Reading

2 Early Gate

Whiteknights

Reading, RG6 6AU

United Kingdom

${ }^{2}$ Research student

Department of Plant Sciences

The University of Reading

Whiteknights

Reading, RG6 6AU

United Kingdom

*Corresponding author. 
Résumé. Deux essais sur le terrain en 1999 et 2003 ont été faits afin de vérifier l'influence de diverses concentrations de sucres appliquées par mouillage des racines à des taux de 25, 50 et $70 \mathrm{~g}$ par litre d'eau, et ce en regard de la croissance des racines et des pousses, de la fluorescence de la chlorophylle, des taux de photosynthèse, et des concentrations en carotène et en chlorophylle chez le bouleau pleureur (Betula pendula Roth.). En dépit de la concentration et de l'année d'application, les sucres de galactose et de rhamnose n'ont pas eu d'effet significatif sur les propriétés de croissance ou de photosynthèse foliaire. Lapplication de sucre de maltose a produit une augmentation de la masse sèche au niveau des pousses et des racines en 1999, mais n'a eu aucun effet en 2003. Le sucrose, le fructose et le glucose ont produit une augmentation de la masse sèche au niveau des racines et des pousses, à la fois en 1999 et en 2003; cependant, les réponses de croissance étaient influencées par la concentration en sucre qui était appliquée. Dans plusieurs cas, l'application de sucre a permis d'accroître le nombre de nouvelles racines qui s'étaient formées lors de la sixième semaine, mais tout en n'ayant aucune influence significative sur la longueur des racines et des pousses déjà existantes. Lors de la vingtquatrième semaine, les accroissements, tant au niveau des pousses que des racines, ont été enregistrés. Lapport de sucre à un taux de 25 g par litre d'eau n'a eu aucun effet significatif sur la fluorescence de la chlorophylle foliaire, les taux de photosynthèse, et les concentrations en carotène et en chlorophylle; cependant, l'apport de sucre à des taux de 50 et de $70 \mathrm{~g}$ par litre d'eau a réduit ces valeurs à partir de la sixième semaine. À la fin de l'expérience, l'accroissement maximal au niveau des racines et des pousses a été observé avec l'emploi de sucrose à un taux de $70 \mathrm{~g}$ par litre d'eau, et ce en 1999 et en 2003. Les faibles taux de mortalité observés chez les arbres traités avec du sucre indique que l'application de sucre pourrait faciliter la survie des jeunes bouleaux suite à leur transplantation.

Zusammenfassung. Zwei Feldversuche von 1999 und 2003 untersuchten den Einfluß einer Reihe von Zuckern, angewendet als Wurzeltauchbad mit 25, 50 und 70 g/L Wasser, auf das Wurzel- und Triebwachstum, Chlorophyll-Fluoreszenz, Photosyntheserate, Blattkarotinoid und Chlorophyllkonzentration von Birken (Betula pendula). Unabhängig von der Konzentration und Jahr hatten die Zucker Galactose und Rhamnose keinen signifikanten Einfluß auf Baumwachstum oder Photosynthesebedingungen. Die Applikation von Maltose vergrößerte das Trieb- und Wurzeltrockengewicht indem Versuch von 1999, aber hatten keinen Einfluß in 2003. Sucrose, Fructose und Glucose vergrößerten das Trieb- und Wurzeltrockengewicht in beiden Versuchen, dennoch wurde die
Wachstumssteigerung durch die Konzentration der applizierten Zucker beeinflusst. In vielen Fällen verstärkte die Zuckerapplikation die Anzahl der neugebildeten Wurzeln in der 6 Woche, aber hatte keinen deutlichen Einfluß auf die Länge der existierenden Wurzeln und Triebe. In der 24. Woche wurden Anstiege bei Wurzel- und Trieblänge verzeichnet. Die Zuckergabe von $25 \mathrm{~g} / \mathrm{L}$ Wasser hatte keinen deutlichen Einfluß auf die Chlorophyll-Fluoreszens, Photosyntheserate, Karotinoid und Chlorophyll-Konzentration, aber Zuckergaben von 50 und $70 \mathrm{~g} / \mathrm{L}$ reduzierten diese Werte in der 6. Woche. In der Bewertung des Experiments wurde der maximale Zuwachs der Wurzel- und Trieblänge mit einer Wurzeltränkung von $70 \mathrm{~g}$ Sucrose/L Wasser in beiden Versuchen von 1999 und 2003 assoziiert. Geringere Sterberaten von zuckerbehandelten Bäumen zeigen, dass Zuckerapplikationen die Überlebensrate von jungen Birken nach der Verpflanzung verbessern.

Resumen. Se llevaron a cabo dos ensayos en 1999 y 2003 para investigar la influencia de un rango de azúcares aplicado en zanjeo a 25 (3.4), 50 (6.8) y $70 \mathrm{~g}$ (10.3 onz) por litro (galón) de agua en raíces y brotes de crecimiento, fluorescencia de clorofila, tasas fotosintéticas, carotenoide de las hojas y concentraciones de clorofila de abedul (Betula pendula Roth.). Independiente de la concentración y año, los azúcares galactosa y ramosa no tuvieron efectos significativos en el crecimiento del árbol o propiedades fotosintéticas. La aplicación de maltosa incrementó el peso seco de los brotes y raíces en el ensayo de 1999 pero no tuvo efecto en el de 2003. Sucrosa, fructuosa y glucosa incrementaron el peso seco de los brotes y raíces en los dos ensayos. Sin embargo, las respuestas en crecimiento estuvieron influenciadas por la concentración del azúcar aplicado. En muchos casos la aplicación de azúcar incrementó el número de nuevos brotes formados en la sexta semana pero no tuvieron efecto significativo en la longitud del crecimiento de las raíces y brotes existentes. Para la semana 24 se registraron incrementos en el crecimiento de los brotes y raíces. Las aplicaciones de azúcar a 25 g (3.4onz) por litro (galón) de agua no tuvieron efecto significativo en la fluorescencia foliar, tasas fotosintéticas, y concentraciones de carotenoides y clorofila. Sin embargo, las concentraciones de azúcar a $50 \mathrm{~g}$ (6.8 onz) y $70 \mathrm{~g}$ (10.3 onz) por litro de agua redujeron estos valores a la semana 6 . Al final del experimento, el incremento máximo de crecimiento de brotes y raíz estuvo asociado con una aplicación de sucrosa a una concentración de 70 g (10.3onz) por litro (galón) de agua en los dos ensayos de 1999 y 2003. Las bajas tasas de mortalidad registradas en árboles tratados con azúcar indican que estas aplicaciones pudieron ayudar a la supervivencia de abedules jóvenes después del trasplante. 


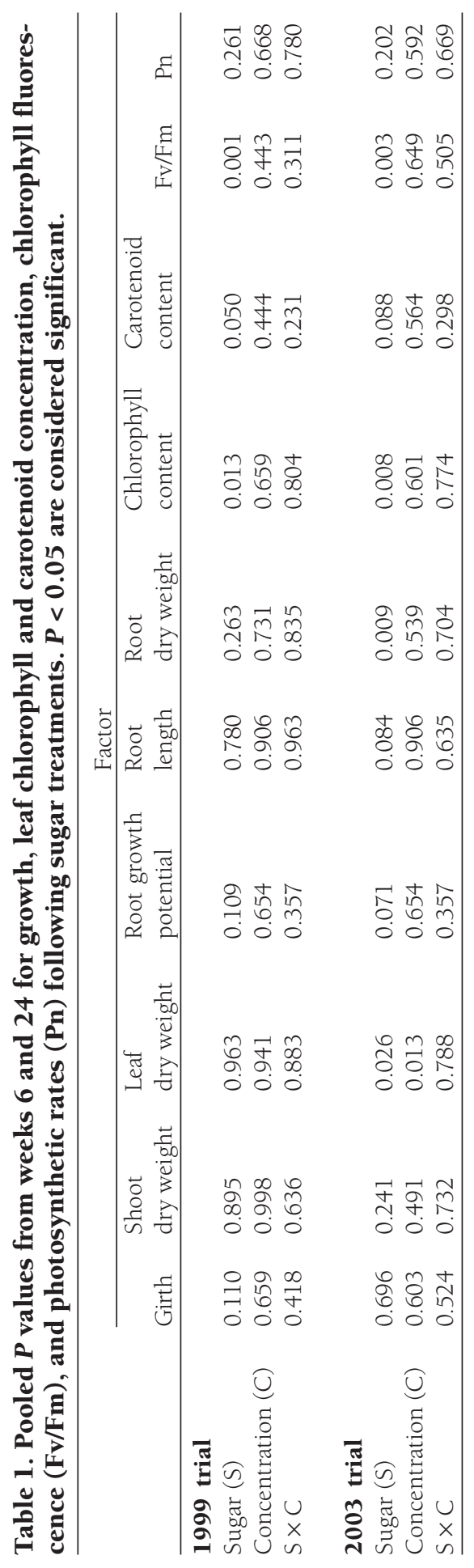




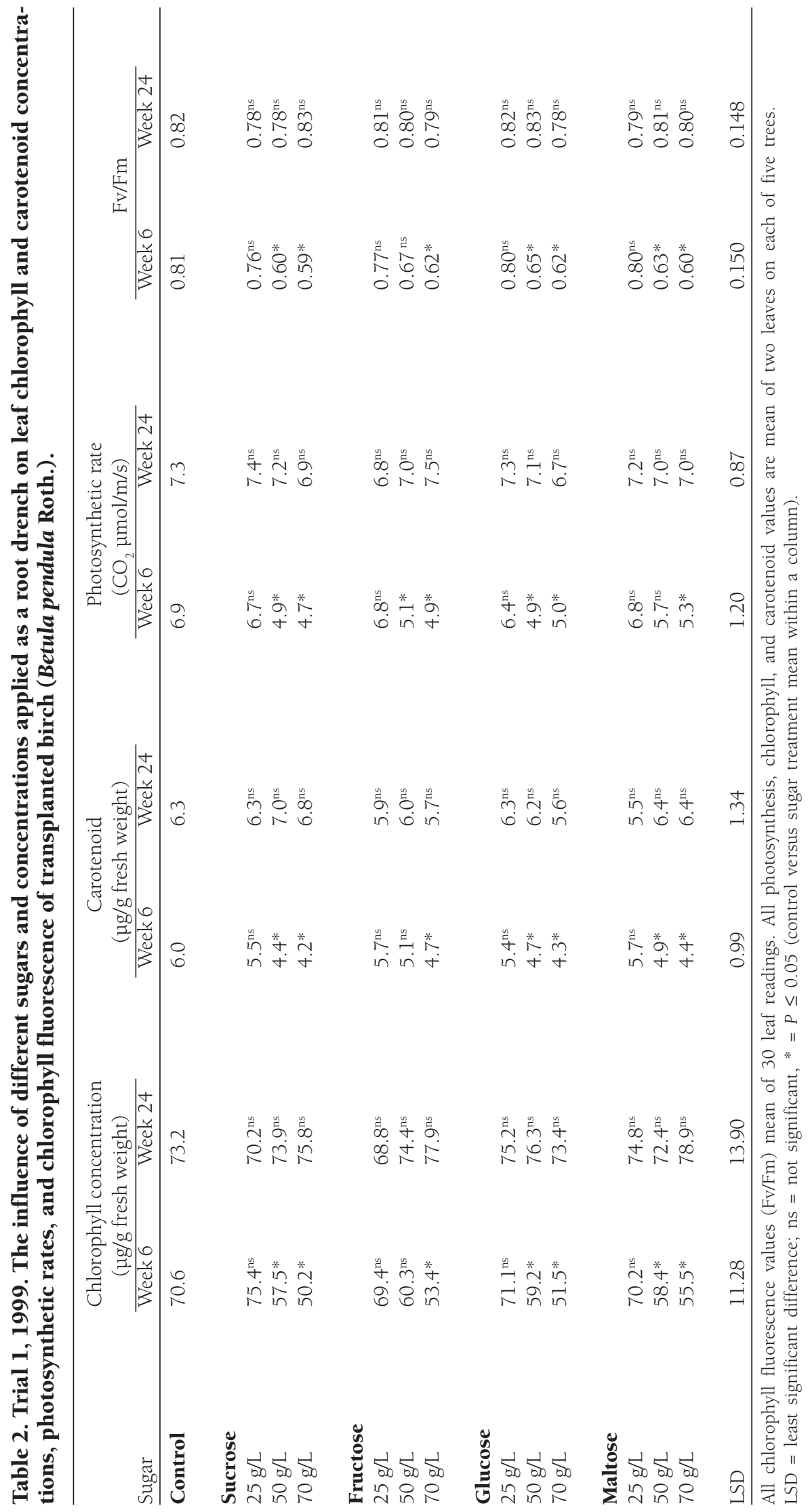




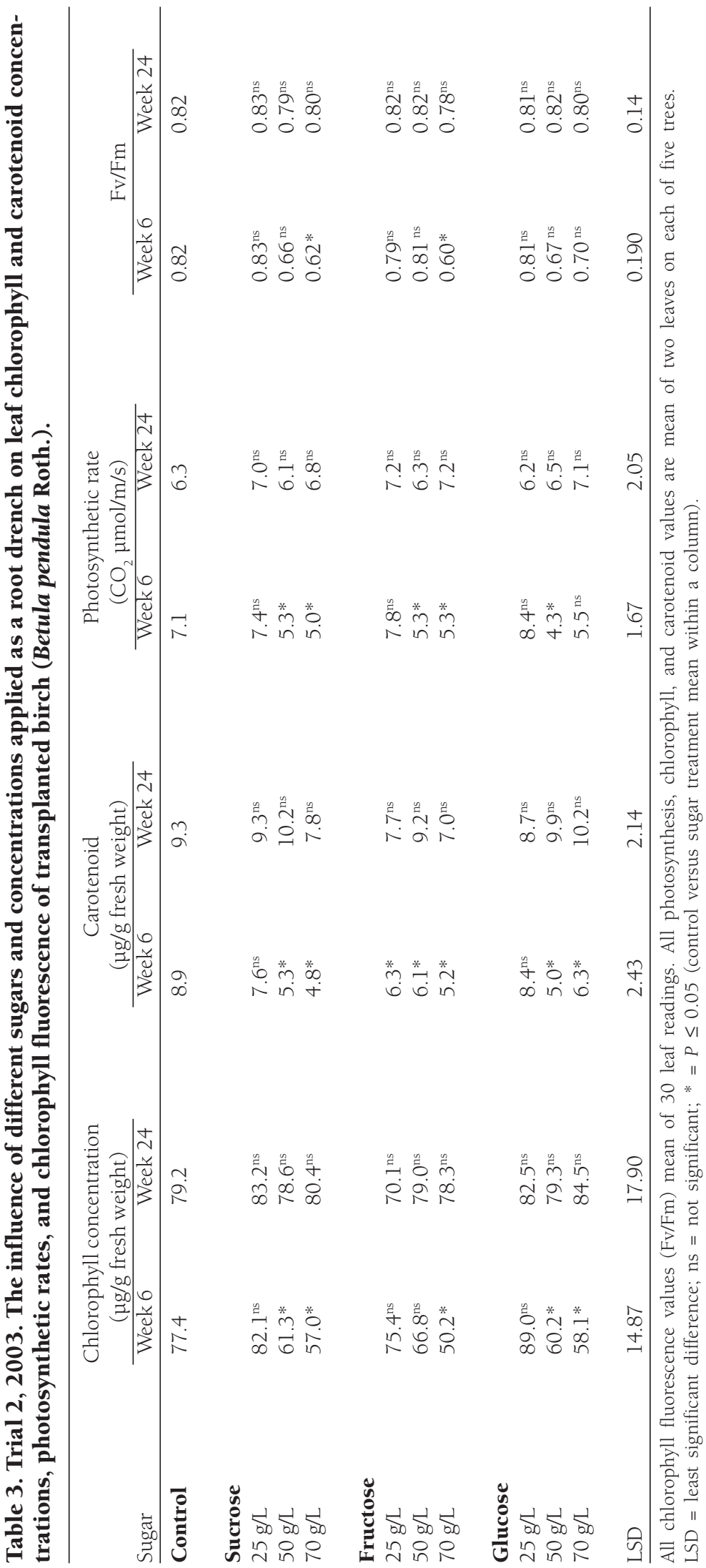




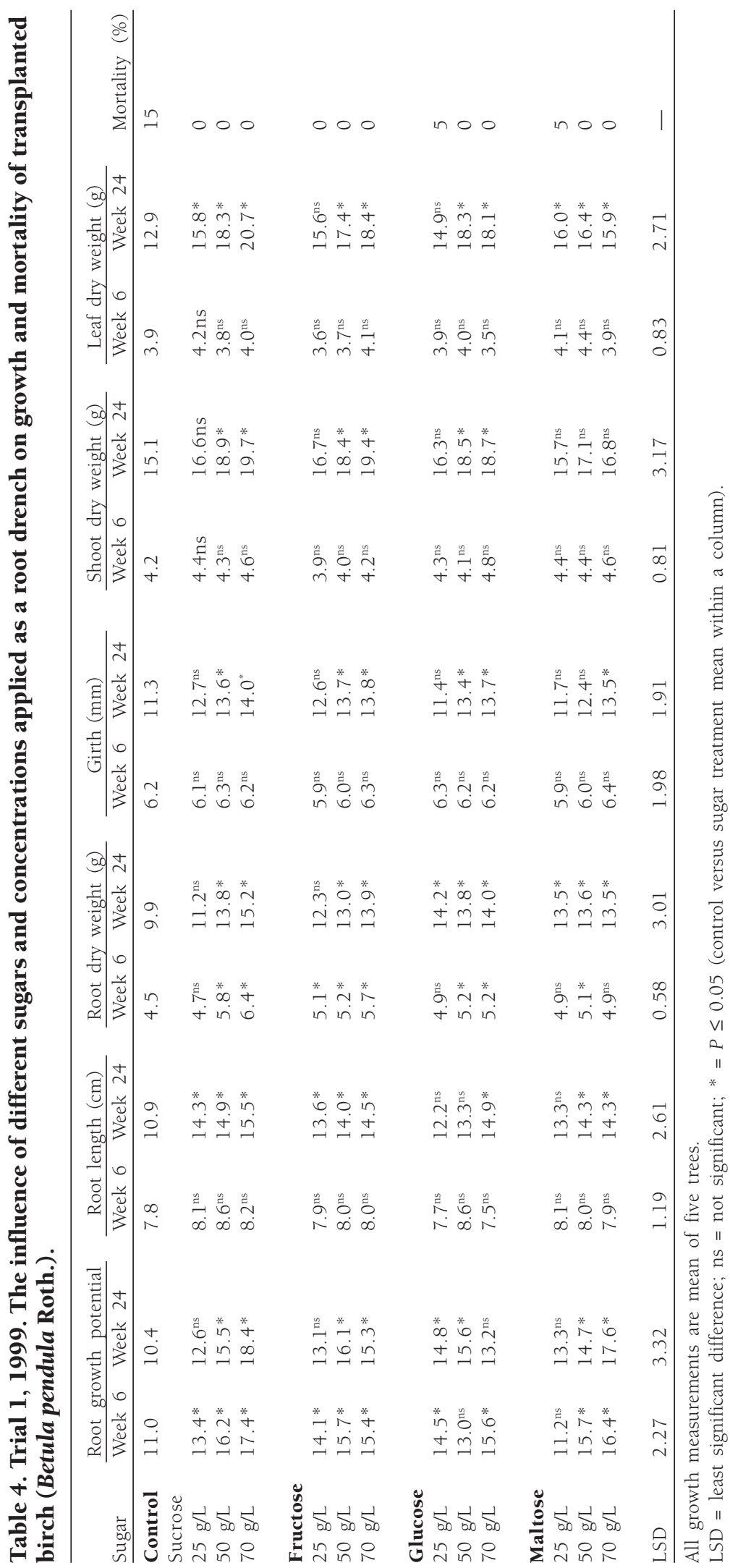




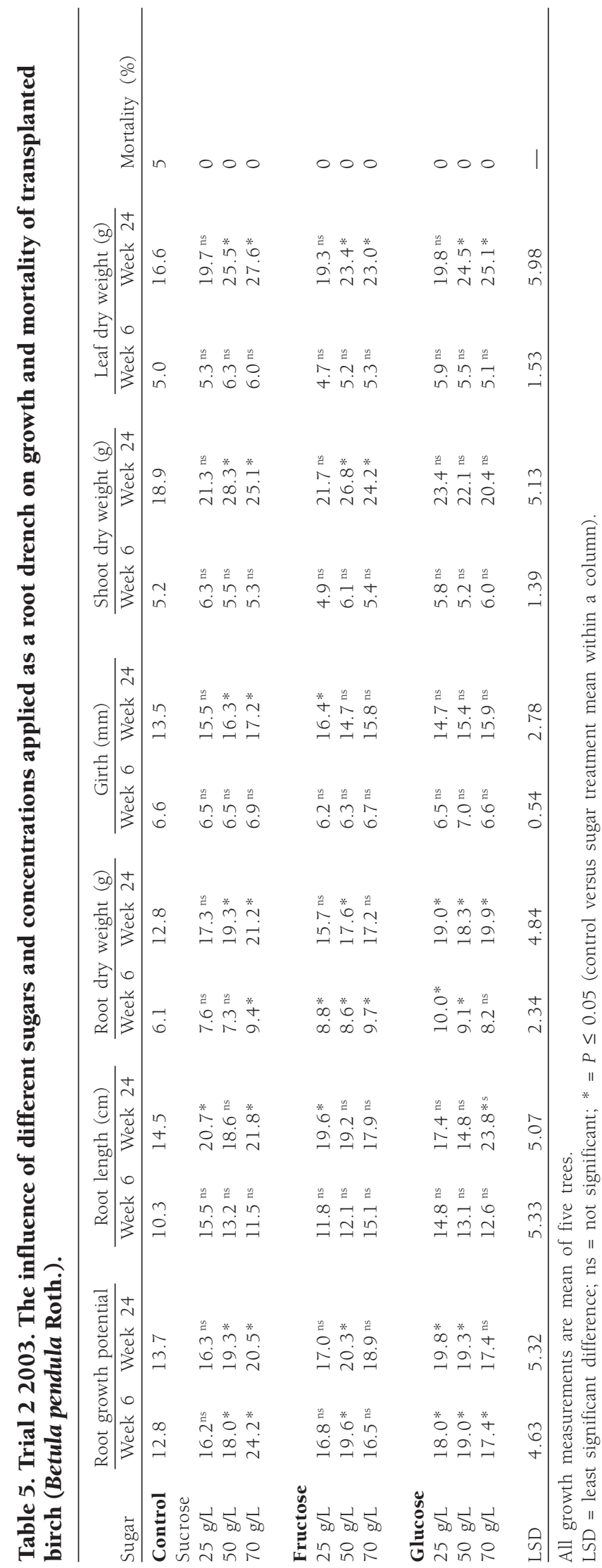

